\title{
Boško Telebaković*
}

Оригинални научни рад

UDK 1 :32(091)

\section{NEKA PITANJA FILOZOFIJE POLITIKE ${ }^{* *}$}

\section{Some issues of philosophy of politics}

Summary: Political philosophy and philosophy of politics take different approaches. The purpose of politics is often forgotten in the former, whereas efficiency is neglected in the latter. The former is more interested in power, reign and state, the latter in moral, justice, freedom, equality and brotherhood.

Key words: philosophy, politics, sense, value, freedom, moral

Sažetak: Politička filozofija i filozofija politike imaju različit pristup. U prvoj se često zaboravlja na svrhu politike, u drugoj na njenu efikasnost. U prvoj je veći interes za moć, vlast, državu, u drugoj za moral, pravdu, slobodu, jednakost, bratstvo.

Ključne reči: filozofija, politika, smisao, vrednost, sloboda, moral

Filozofi se od davnina zanimaju za politiku. Vremenom je oblikovana posebna filozofska disciplina - filozofija politike. Političari obično zaobilaze filozofiju kao neupotrebivo mudroslovlje. Filozofi se obraćaju svima koji teže nešto da proniknu, a filozofi politike onima koji žele da shvate smisao i vrednost politike. Filozofi vekovima govore o važnosti "znanja neznanja". Ruso je spominjao sposobnost predviđanja da se neke stvari ne mogu predviđati. Ne nagađa se samo u svakodnevnom životu. Kelzen je opominjao da Pilatovo pitanje šta je istina, kojim se bave filozofi, nema konačan odgovor. U politici je takođe zanimljivo šta je istina, ali se umesto nje često nudi volja nekih ili odluka većine. Filozofi i političari pitaju da li se sme biti tolerantan prema neistini. Niče je smatrao da stiže vreme kada će iznova morati da se uči šta je politika. (Niče, F., 1991: § 960) Po Veberu je većina građana politički neobrazovana i nezainteresovana za politiku.

U političkim naukama je u prvom planu potreba da se pojave opišu, uoči šta ih pokreće i kakve posledice izazivaju, da bi se ispitala politička efikasnost. Filozofiju politike pokreće potreba da se razume suština političkih pojava, pa se razmatra složen međuodnos političkih ciljeva, sredstava i rezultata, da bi se moglo prići smi-

\footnotetext{
* Redovni profesor filozofije na Fakultetu političkih nauka Univerziteta u Beogradu

** Rad je nastao u okviru naučno istraživačkog projekta Univerziteta u Beograd - Fakulteta političkih nauka Politički identitet Srbije u regionalnom i globalnom kontekstu (ev. broj 179076), koji finansira Ministarstvo prosvete i nauke Republike Srbije.
} 
slu neke politike. Njena vrednost se ne može meriti samo ciljevima ili sredstvima ili rezultatima. Zbog čega, zašto, kako i koliko dobro su pitanja koja se prilikom procenjivanja politike ne bi smela razdvajati. Zbog naglašavanja razumevanja, mnogi filozofiju politike smatraju arhaičnom disciplinom koja ne odgovara 'duhu vremena". Njima je stalo do održavanja "'vremena bez duha", jer se u takvom vremenu najbolje snalaze. Ne odgovara im ovakva disciplina, nepodobna za one bez znanja o filozofiji i o politici. Ona nije analfabetski tečaj, kakvi su danas često u modi. Ono što se proučava u filozofiji politike je u stalnoj promeni, pa je važno obezbediti teorijsku otvorenost i stalno ispitivanje smisla i vrednosti raznih programa za akciju, sprovođenja tih programa i teorijskih i stvarnih sukoba koji su posledica različitosti programa. Pri tome je važno promišljanje raskoraka politike kakva jest, politike kakva se predstavlja da jest i politike kakva bi mogla da bude, ukoliko bi bile ostvarene najbolje stvarne mogućnosti. Teorija politike, u kojoj se pokušava razumevanje raznih vidova političkih pojava, može se nekad približavati filozofskom stanovištu, ali je danas često nastojanje da se ova disciplina potpuno "očisti" od svega filozofskog.

Filozofija politike je povezana s raznim filozofskim disciplinama. Ona ne može da počne bez određenja ontološkog, gnoseološkog, aksiološkog, antropološkog osnova politike i bez promišljanja metoda filozofije politike. Povezana je s filozofijom društva, etikom, filozofijom prava, filozofijom istorije. Istorija se u filozofiji politike shvata različito, kao poprište moguće slobode i kao vreme u kome se javljaju novi oblici neslobode, a razni oblici nasilja i manipulisanja javnošću i pojedincima utiču na odustajanje od istine i odlaganje slobode.

Filozofija politike se razlikuje od političke filozofije. Valja podsetiti na razliku hrišćanske filozofije i filozofije religije: prva je ispunjavala zadatke koje joj je davala crkva, druga se razvila potvrđujući svoju nezavisnost u odnosu na crkvu. Po Šmitu su svi važni pojmovi moderne nauke o državi sekularizovani teološki pojmovi. (Schmitt, C., 1979: 49) Da li je filozofija politike uvek nezavisna, a politička filozofija zavisna od neke politike? Politička filozofija često dobija zadatak da pomogne $\mathrm{u}$ racionalizovanju nekog političkog ustrojstva, a nekad i da pomogne njegovom autolegitimizovanju, koje nikada nije dugoročno uspešno i služi samo kao sumnjivo privremeno rešenje. U socijalističkim državama bilo je dovoljno racionalizovanje, jer se smatralo da su tekstovi klasika obezbeđuju legitimizovanje. Bilo je važno i maskiranje dnevnopolitičkih ciljeva. Na Zapadu politička filozofija često treba da objasni pojedine političke odluke i ubedi da će od njih imati korist većina građana. Dešava se da onda, kada podupire opoziciju, treba da uobliči teorijsko osporavanje vladavine. Nekad se politička filozofija ne libi da se otvoreno deklariše kao deo neke politike ili njene ideologije, a nekad "glumi" političku neutralnost.

Filozofija politike najčešće brine o nezavisnosti u odnosu na političke moćnike. Zato onaj, koji ne može da se iskobelja iz političkih poslova, nije u stanju da se bavi filozofijom politike. Da li primer Platona opovrgava ovu tvdrnju? Platon je želeo da uđe u prostor političkog odlučivanja, ali nikada nije bio u tom prostoru. Njegova putovanja, vođena namerom da se pokuša brisanje razlike filozofije i politike, bila su neuspešna. Za stare Grke je cela filozofija bila škola čovečnosti, a njeni 
praktičko-filozofski delovi su bili posvećeni pre svega tome. Kod Dekarta je filozofija škola razumnosti, a ne čovečnosti. Praktična filozofija je suprotna spekulativnoj i služi kao osnov prirodnih nauka. U toj filozofiji cilj nije otvaranje pristupa smislu, već obezbeđivanje primenjivog znanja. Filozofi politike više teže otkrivanju smisla, politički filozofi prikupljanju i prenošenju primenjivog znanja.

"Šta je politika" nije pitanje političara. Oni ga ne postavljaju i podrazumevaju da se zna čime se bave i da oni sami to znaju. Ako efikasno delaju, osećaju puls društva, moguće ciljeve države i namere jačih od nje, donose prikladne odluke o onom što je u njihovoj moći i nameću ih drugima, nikome neće pasti na pamet da proverava da li znaju šta je politika. Oni koji postavljaju to pitanje nisu političari i obično i ne misle da se politika može svesti na ono čime se bave političari ili na ' zbirku recepata" koju bi morao da prouči onaj koji hoće da se održi u političkom karakazanu. Političar odlučuje i nije mu, kako je tvrdio Al Farabi, potreban politički nauk. Oni oko njega administriraju, pomažu da odluke stignu do izvršilaca i budu ostvarene. Karl Šmit je smatrao da "olitičko" i nema sopstvenu supstanciju. Država označava politički status nekog naroda. Na nivou države se odlučuje o stupanju u rat, o žrtvovanju života državljana. Politika je "pre kao i sada sudbina". Po Lasvelu se politička nauka ne može oštro razdvojiti od drugih društvenih nauka. Za Henisa je politička nauka, fiksirana na problem vlasti, slepa za suštinu društvenih i političkih preobražaja. 'Fenomeni političkog postaju politički fenomeni samo zahvaljujući upitnosti, zahvaljujući značaju koji imaju za način ljudskog zajedničkog života." (Henis, V., 1983: 17) Političar treba da bude u stanju da ostale ubedi da mu je jasno koji je cilj politike i kakva politička sredstva treba upotrebi da bi cilj bio postignut. Najvažnije je da mu poveruju kako može da donosi prave, pravovremene i opštekorisne odluke. Ne veruju mu ako brine pre svega o svojim interesima. Političar treba da bude prepoznatljiv i po političkom govoru, različitom i od svakodnevnog i od teorijskog govora. U političkom govoru se krajnosti često dodiruju, ali zajedno ocrtavaju smer ka onom što je u pozadini određene politike i može da posluži kao putokaz njenog razumevanja. Greši vlastodržac koji uvažava parolu '"vođa je uvek u pravu" i nastoji da po svaku cenu obezbedi večno sećanje i izbegne "'damnatio memoriae". Na grobu bi mogla da mu stoji poruka s indijskih grobalja "molite se da se ne vratim".

"Ars politica" je od antike ne samo umeće već i javni posao, ali i nekakva teorija koja povezuje prošlost i budućnost. Ozbiljna teorija politike se oslanja na istoriju političkih teorija. Dobar političar zna da mu istorijsko znanje pomaže da ne pravi greške koje je mogao da izbegne. Loš političar se batrga od jedne do druge greške, sve dok ga trpe kao političara. Shvatanja politike se mogu oblikovati na više načina. Po Berku je praktična politička mudrost usmerena novom, a politička teorija onom opštem i uvek važećem. Politički novo može da bude rukovođeno državnim razlogom, što je na tragu Makijavelija, ili načelom uspostavljanja političkih ustanova, što je na tragu Hopsa. Po Habermasu se moderno društveno-političko učenje oblikuje razlikovanjem društvenog poretka i državnog razloga. Učenje o najboljem poretku često se zamenjuje učenjem o legitimnosti, a učenje o državnom razlogu učenjem o efikasnosti vlasti. Mnoge zanima jedino može li teorija da uputi na uspešne praktične 
političke metode, a ne i koliko je ona sama valjano zasnovana. Od Makijavelija i Hopsa se smanjivao broj onih koji razmišljaju o svrsi političkog delovanja. "Sapere aude" (potrudi se da sam razumeš), poručivao je Kant. Zahtev je i politički program: samo razum treba da vlada, jer je on najviši autoritet. Ono što nije razumno, ne može nikog da obavezuje. Mnogi se nisu usudili da kritički preispituju sve oko sebe, a naročito su zaobilazili politiku. Oni koji su pokušali da je razumeju nisu mogli da se slože. Neki su poput Šilera smatrali da je čovek stvoren slobodan, makar se rodio i u okovima. Pojedinac ima svoja prava koja nijedna država ne može da mu oduzme. Drugi su smatrali da niko ne može zaista da bude slobodan sam. Nema oslobođenja bez promene društva. U Francuskoj revoluciji i kasnije su bila prisutna oba shvatanja.

Oni koji razmišljaju o politici mogu da izađu iz datog političkog prostora i udalje se od sadašnjosti. Političari se obično trude da se oslone na stvarnost, jer bez ovog oslonca njihovi poduhvati ostaju neuspešni. Neki namerno komplikuju stvari, "mute vodu", da bi se onda predstavili kao stručnjaci za rešavanje nerešivih situacija. Iako se tako ponašaju iz racionalnih razloga, doista su politički mutnolovci. Nevolja je što "politikanti", koji "vode politiku" a ne rešavaju probleme, glumataju a ne odlučuju, obećavaju a ne ispunjavaju obećanja, često preovlađuju i na najvišim političkim nivoima. Po Benediktu XVI, tamo gde politika hoće da bude izbavljenje, ona previše obećava. (Ratzinger, J., 2004: 104) Problem je što i građani nemaju dovoljno interesa za dobar život i dobro ponašanje. U svetu vladaju dosada i glupost. Ljudi obično ne gledaju dalje od nosa, žive od danas do sutra, ne razmišljaju koga će takvim ponašanjem ugroziti. Najveći deo ljudi ne pita šta je istina, ne razmišlja o slobodi i ispitivanju njenih granica. Zato ima život kakav zaslužuje: bez ispunjenosti, prisnosti, radosti i mogućnosti ličnosti. Slično je s ljudskim zajednicama. One u kojima se prihvataju svi zahtevi moćnijih nisu dugotrajne. Za Habermasa je građanska neposlušnost test demokratske pravne države. U filozofiji politike se uzimaju u obzir razni vidovi realne politike, ali i najvažniji pokušaji teorije politike da bude shvaćeno ono što se dešava u prostoru politike i ono što je u njemu izgrađeno. Šta spada u taj prostor? Po mnogima tu spada i svakodnevni život, a po nekim feministkinjama i prostor između šporeta i spavaće sobe, što bi moglo da se smatra i vidom obnovljenog političkog pristupa "panem et circenses". Po pluralistima, svi građani učestvuju u politici. Fuko bi tvrdio da neki učestvuju poslušnošću, pristajanjem da im zakržljaju telo i duh, drugi buntovništvom. Oni koji "vezuju konja gde im gazda kaže" uvek su bili u većini. Možda je u savremenom svetu i uzdržavanje od politike politika?

Dok se u političkoj teoriji obično insistira na znanju o političkim zbivanjima i strukturama, u filozofiji politike se ovo znanje uzima u obzir, ali postavljaju i pitanja o suštini, smislu i vrednosti politike. Filozofiju politike mnogi vide kao uglavnom preskriptivnu, a teoriju politike kao pre svega deskriptivnu disciplinu. U etici se takođe postavljaju pitanja o promišljenom delovanju, ali pre svega delovanju pojedinaca, i pokušava se ustanovljavanje moralnih normi. Delovanja pojedinaca i njihovi složeni odnosi imaju i svoje političke likove. Politika je dugo bila čvrsto povezana 
s etikom. U renesansi se razvila svest da moralni obziri mogu da ometaju političku efikasnost. U nekim kasnijim režimima, recimo u staljinizmu i nacizmu, pokazalo se kako fanatično pridržavanje načela ispražnjenih od morala vodi monstruoznoj politici. Po mnogima i pravda mora da ostane daleko od politike. U poslednje vreme se ona opet spominje, mada je pitanje koliko se doista uzima u obzir. Priču o prirodnim pravima su mnogi kritikovali. Bentam ju je označio kao "'budalaštinu na štulama", Mekintajer smatrao jednakom " verovanju u veštice i jednoroge". Za Marksa, ali i za konzervativce, prava zavise od društvenih odnosa. Mnogi su se protivili da u ljudska prava budu uključena i ekonomska i socijalna prava i tvrdili da je svaka para za siromašne i gladne nagrada za lenjost i porok. Kada se u teoriji politike zaobilazi veza s filozofijom politike, to obično znači da se neka važna pitanja ostavljaju po strani. Kada se u filozofiji politike zanemaruju neka pitanja interesantna za političku teoriju, to može da znači da se od interesovanja usmerenog neposrednoj stvarnosti prelazi na promišljanje koje teži da prevaziđe uske vremenske okvire, a da pri tome ne izgubi vezu sa životom. Filozofija politike i teorija politike mogu da budu veoma udaljene, ali su tada verovatno obe discipline na gubitku. Dok su teoretičari politike često prvo uočavali moć i državu, a priču o odnosu politike i morala smatrali prevaziđenom, filozofi politike su obično i dalje smatrali da se ne sme zanemariti ni odnos politike i morala. Često su prilično udaljeni mislioci slično razmišljali o odnosu politike i morala. Na primer, Karl Šmit, koji je promišljao očuvanje građanskog društva, i Đerđ Lukač, koji je razmišljao o mogućnosti njegovog prevazilaženja, prilično su bliski kada je reč o odnosu politike i morala. (opširnije: Rodin, D., 1985: 82ff) Moral je mnogim političarima sličan pesku u cipelama: sprečava ih da sigurno gaze. Po nekima, treba odrediti "moralni minimum" koji ne ometa politiku. Drugi ne odbijaju da se osvrću samo na moralno dobro, već recimo i na "dobro u prostoru politike". Zato im se dešava da upadnu u kovitlac "'rđavog u prostoru politike”. Dostojevski je u "Zapisima iz mrtvog doma" tvrdio da je zločin svuda zločin, bez obzira na razne pristupe, sve dok može da se tvrdi da postoji čovek. Filozofi politike ne odbijaju razmišljanje o moći i državi, ali uglavnom misle da je interesantnije ono teško uklopivo, ono što nas “'žulja”. Po Nojmanu, većina ne može da pretvori zlo u dobro, već zlo uz podršku većine postaje veliko zlo. (Neumann, F., 1974: 177) Nepravda se glasanjem ne pretvara u pravdu, ni neistina u istinu.

Po Hani Arent, političari na Zapadu "'rešavaju probleme" bez promišljanja suštine problema i posledica svojih odluka. Bez obzira koja je partija vladajuća, izgleda da vlada "politika politikanata". Svi se slažu da je demokratija dobra, ali se mnogi pitaju da li su njeni ciljevi dostižni. Demokratska procedura ne može da spreči da većina ugnjetava manjinu ni da grupni interes nekad bude važniji od opšteg. "Srednji glasač" može da odredi pobednika na izborima, ali ne i da utiče na to ko će zaista da vlada, jer u posleizbornim vladajućim koalicijama mogu da budu zastupljeni i oni za koje je glasao "'ekstremni glasač”. Na Istoku su se političari oslanjali na teoriju koju su smatrali potpuno istinitom i progonili neortodoksne mislioce. Smatrali su da je budućnost sigurna, da problema nema, iako ih je bilo sve više. Jedna partija je isključivala političku utakmicu. Nije bilo odgovornih zbog loših odluka. Posle 
raspada "'gvozdenog carstva" i "samoupravljanja odozgo", pokušano je izbegavanje "politike politikanata", ali je ni u jednoj zemlji nisu prevazišli. Negde su se mafiozi približili vlasti ili čak stvorili kakiokratiju (vlast pokvarenih), goru od pletokratije (vlasti mase). Laski je upozoravao na opasnost zloupotrebe politike. (Laski, H., 1934: 37) Može li se politika "'dobro upotrebljavati"? Ko to treba da procenjuje? Ko bi štitio od zloupotrebe? Možda " policy mix" postaje sve sličniji u raznim delovima sveta, jer pritisak svetskih ekonomskih moćnika ujednačava politiku? Pogrešno je, međutim, govoriti o "kraju politike" ili prihvatati parole o njenom dobrovoljnom samoosakaćivanju. Radi se o preoblikavanju prostora politike, koje nije prvo i neće biti poslednje. Ono podstiče ljude da menjaju načine života, privikavaju se na neizvesnost, nesigurnost i neslobodu. Bez politike se i dalje ne može, ali je potrebno ponovo promišljati njene temelje, sadržaj i granice.

Ne može se biti uspešan političar bez iskustva i veštine, koja uključuje i sposobnost veštog laganja. Kaže se da vlastodršcima priliči da lažu, ostalima ne. Lažov je čovek od akcije, onaj koji kazuje istinu to nije. (Na primer: Platon, Država, knjiga III, V) Verovatno nijednom ljudskom stvorenju ne priliči da laže, ali se političarima laganje često oprašta. Ne može se biti filozof bez spremnosti da se uprkos svemu bude na strani istine. (Arent, H., 1994: 48) Sme li filozof da se ponaša kao da laž ne postoji? Sme li da se pomiri s uporednim postojanjem istine i laži?

Ko danas određuje pravila "'ars politicae"? Da li je još moguće nabrojati pristupe promišljanju politike? Moderna politička teorija i pored poplave tekstova izgleda osiromašeno. Nedostaju joj dobro utemeljena i obuhvatna učenja, a čitav niz ranije isprobanih pristupa je zapostavljen ili neopravdano napušten (na primer, pristup nazvan "vladarsko ogledalo"). Retko je nastojanje da se važna politička pitanja osvetle sa stanovišta filozofije politike. Ona može ljude da upozori na opasnost, pa se bez nje lakše obavlja manipulisanje i kontrolisanje. Još kod Štala su umesto filozofije politike spominjani učenje o državi (Staatslehre) i veština upravljanja državom (Staatskunst). Oni, koji uviđaju siromaštvo političke teorije očišćene od filozofske upitnosti, teže da naprave most između filozofije politike i političke nauke. Pri tome često interpretiraju stanovišta obe strane tako da nijedna strana time ne može da bude zadovoljna.

Kaže se da su se u Springfildu u Minesoti “'dobri" i "zli" ljudi dugo sporili, a onda se razgraničili i živeli po različitim pravilima. SAD, u skladu sa Springfild doktrinom, neke države oglašavaju za "dobre", druge za "loše". Međutim, državama koje su proglašene za "loše" ne dopušta se da žive po svojim pravilima, već se silom dovode u red, odnosno nameću im se pravila. Srbija i Republika Srpska su se našle u grupi loše procenjenih, prema kojima se slobodno primenjuju nelegalna sredstva, uključujući i "vojni humanizam" i terorizam "nevladinih organizacija nasilja".

U filozofiji politike bi morali da budu razmatrani sa stanovišta filozofije i politička stvarnost i razni oblici svesti o njoj. Politika objedinjuje i one koji se slažu i one koji se mrze. U političku stvarnost ne spadaju samo različiti oblici političkog ponašanja, zadobijanja i potvrđivanja moći, ustrojstava vlasti i ispoljavanja države 
i pod-državnih i nad-državnih konstrukcija, već i prostor u kome se ta ponašanja dešavaju i te strukture postoje (čak i politički sajber-prostor). Kod usaglašavanja i sukobljavanja se podrazumeva postojanje različitih potreba i interesa, ali se ka razrešenju različito nastupa. Čovek racionalnim delom svoje prirode naginje usaglašavanju, iracionalnim sukobljavanju. Politiku je teško svoditi na racionalan izbor, kada se na njega može uticati na razne načine. Iako se usaglašavanje uvek zvanično smatra poželjnijim oblikom politike, uvek se iznova pojavljuje i sukobljavanje.

Da li politika-teorija ima samo zadatak da razume politiku-praksu? Treba li da razjasni političko delovanje koje se zbilo ili je u toku ili i da bude njegova prethodnica? Možda bi morala da ima obe uloge? Politički život je bogat i uvek se javljaju nove situacije i strukture koje izlaze iz okvira dotadašnje teorije. Može li se u politici-teoriji izbeći pristranost, koje je teško osloboditi se u politici-praksi? Da li je teorija u stanju da u džungli političkog delovanja stigne do racionalnog sloja? Možda je politička teorija totalizovanje uvek prerano zaustavljeno ili izgubljeno u lavirintu iracionalnog? Možda valjana teorija mora u svakom trenutku da računa s iracionalnim? Perikle je rekao: "Mada samo nekolicina može da oblikuje politiku, svi smo sposobni da sudimo o njoj". Drugi deo suda treba da bude opravdanje onog što se tvrdi u prvom delu, a što upućuje na suštinu demokratije u POLIS-u, čiji je zagovornik bio i Perikle. Svi nikad nisu bili sposobni ni da sude o politici. Da li bi, ako bi svima bila otvorena mogućnost osposobljavanja, bilo potrebno izdvajanje onih koji oblikuju politiku? Teorija politike često ne može da obezbedi dovoljnu distancu za obuhvatno sagledavanje političkih pojava. Filozofija politike može svojim pristupom i odstojanjem od politike da doprinese njenom razumevanju. Malo je teoretičara politike koji ovo shvataju. Zato nude i objašnjenja koja se brže menjaju od ženske mode.

U teoriji politike je vidljivo okretanje od ontološkog i aksiološkog ka empirijskom i instrumentalnom. Može li teorija politike bez ontološkog i aksiološkog utemeljenja? Ona ne bi smela da pokazuje samo kako dalje, već i kuda dalje. Ona ne treba da odgovara samo na pitanja ko je u stanju da upotrebljava moć, kako se zauzima povoljna pozicija u procesu moći, kako se moć održava i upotrebljava. Na sva pitanja u vezi politike može se odgovoriti jedino ako se imaju u vidu ukupno društvo i njegova istorija. Mora se računati i s pojedincem udaljenim od moći. Politički subjekt je i najslabiji pojedinac. Nekad se tvrdi da cilj prave politike treba da bude osnaženje pojedinca, jer jedino tako kolektiv može da bude siguran da će izdržati i najveće političke zemljotrese. Traženje saglasnosti pojedinca nije dovoljno za prepoznavanje prave politike, jer se saglasnost može obezbediti raznim političkim tehnikama, a da pojedinac ne bude svestan šta je doista predmet saglasnosti i koliko štetu od nje može da ima. "Prava politika" se određuje kao smanjivanje rastojanja između onih koji vladaju i onih kojima se vlada, a nekad se čak spominje i ukidanje ove razlike. To bi, međutim, bilo jednako ukidanju države, odnosno izlasku iz dosadašnjeg civilizacijskog okvira u kome je političko uvek vezivano za vlast i državu. Da li je pominjanje prave politike utopijsko? Da li je utopija potrebna ljudima kao pravi, mada nedostižan cilj, ili da bi, naslonjeni na nju, ostali dalje zajedno u ne- 
utopijskoj zajednici? Utopija može da bude i jedno i drugo: i slatka prevara i deo konkretnog projekta promene čoveka i sveta. Politika ne bi smela da bude previše gorka, da ne bi odbijala od sebe, ni neistinita, da se ne bi zaboravljalo kako, zašto i kuda vodi. Ona ne treba da ometa delovanje ekonomije, ali bi morala i da omogućuje i uvećava prostor delovanja kulture.

U filozofiji politike se podrazumeva da značenje politike nije konačno određeno i da je u stvarnom svetu pitanje šta je politika, čak i kad se glasno ne postavlja, političko pitanje. Po Berlinu se u svetu sukobljenih ciljeva može raspravljati o političkim ciljevima i sredstvima. U svetu jednog cilja podrazumevaju se sredstva za njegovo postizanje, a rasprava je isključena. (Berlin, I, 1988: 149) U filozofiji politike je pitanje šta je politika pre svega filozofsko. Pojedini pojmovi, kojima se pokušava razjašnjenje, određuju se različito. Za neke se tvrdi da se odnose samo na političke izuzetke. Možda raznovrsnosti političkih pojava mora da odgovara mnoštvenost pojmova i raznovrsnost njihovih značenja.

Za ljude nema važnijeg pitanja od slobode. Šta je sa slobodom volje? Platon je spomenuo Leontiosa koji je naišao na leševe kraj zida Atine, poželeo da ih posmatra, pokušao tome voljno da se odupre i odvratio pogled od njih, a onda se ipak okrenuo i gledao ih. (Platon, 1983: 439e-440a) Po Avgustinu je sloboda volje uzrok zla u svetu, po Tomi Akvinskom čovek može slobodno da se opredeli za dobro ili zlo. Za Dekarta je problem što se volja ne povodi uvek za umom. Volter je smatrao da je postupanje slobodno, jer čovek uvek radi samo ono što hoće, ali ne i volja, koja sledi razum. Za Hjuma je volja određena uslovima života. Po Kantu je slobodna volja neshvatljiva, ali je njena autonomija osnov ljudskog dostojanstva. Po Hegelu, u slobodi je nužnost, a umni pojam slobode sadrži u sebi ukinutu nužnost. Za Hartmana je sloboda volje sloboda da se nešto hoće, a ne da se nešto sme. Po Šopenhaueru, čovek može da čini ono što hoće, ali ne može da hoće sve što bi hteo, odnosno razlikuje se sloboda postupanja od slobode volje i postojanje slobode postupanja ne znači da mora da postoji i sloboda volje. Dostojevski je smatrao da sloboda previše zahteva, da to izaziva patnju, pa je nesrećni ljudi zbog toga često odbacuju. Možda se stalno mora promišljati mogućnost "oslobođenja slobode" i delovati tako da se ova mogućnost ne zatvara već otvara? Velika nevolja traži veliko promišljanje.

Suština politike se najbolje vidi iz njenog odnosa prema slobodi. Iako su ljudima činilo da su neka stvorenja slobodna, pa se kaže "slobodan kao ptica", jedino čovek može da oseća da je sputan i da treba da teži slobodi. Obično ne pokušava da bude sličan ptici i luta svetom, jer je skitnica često gladna i žedna. Politička ustrojstva različito ograničavaju slobodu. Nije dovoljno biti formalno slobodan. U teoriji politike se priča o slobodi nekad smatra prevaziđenom. Zar ljudska težnja slobodi može da zastari? U svakodnevnoj političkoj praksi nije moguće stalno osvrtanje na slobodu, ali ona ne bi smela da bude sasvim izvan vidokruga politike koja ljudima obećava dobar život. Osvrtanje nije pravi termin, jer je sloboda uvek ispred nas. Kada smo povijeni do zemlje, ne vidimo slobodu. Tek kada se uspravljamo i dignemo glavu, možemo da je nazremo. U filozofiji politike sloboda nije jedan od pojmo- 
va, već ključ koji može da otvori mogućnost filozofskog razumevanja osnova neke politike i procenjivanja njenih rezultata.

Ideja slobode možda počiva i na priznanju jednakosti prirodno nejednakih ljudi. Čovek, po Periklu, ne može da bude slobodan ako mu nije priznata jednakost s drugima. Mnogi su smatrali da je početno priznanje jednakosti prepreka slobodi. Po lordu Ektonu, jednaki ne mogu da budu slobodni. Ljude često više pogađa osećaj nejednakosti nego nemogućnost dosezanja pune slobode. Napreduje li se ka slobodi ako se prihvati početna nejednakost ljudi, ali zahteva da se prema njima jednako postupa? Može se pitati koji je vid jednakosti neophodan za slobodu, a koja vrsta nejednakosti mora da bude zadržana da bi mogli da budu očuvani smisao i vrednost slobode. Ekonomska nejednakost je često bila politički problem. Sve revolucije su se lomile na "tvrdom orahu jednakosti". Francuska revolucija nije uspela da sprovede proklamovanu jednakost. U Oktobarskoj revoluciji probuđena je nada da će jednakost biti ostvarena, ali je nada i tada izneverena. Može li demokratija da bude skladno spojena s jednakošću ili su građani jednaki samo u nemogućnosti da zaista utiču na odlučivanje i na kontrolisanje sprovođenja odluka? Ako imati jednaka prava s drugima, jednake spoljne početne mogućnosti, znači otvoriti vrata slobode, težiti pravom čoveku, onda su vrata uvek ponovo zatvarana. Čovek još nikad nije mogao da bude ono što bi morao da bude. Govor o slobodi i jednakosti je i rasprava o putu ka čoveku i pravim odnosima među ljudima. Razočaranost zbog neslobode i nejednakosti na Zapadu i Istoku nije poništavala problem puta ka boljem svetu.

Izgleda da je i bratstvo teško usaglasivo sa slobodom. Mogu li ljudi zaista da budu zbratimljeni? Kaže se da su braća zajedno u dobru ili zlu, ali se zaboravlja da mogu da budu zajedno jedni s drugima ili zajedno jedni protiv drugih. Druga mogućnost kao da je češće ostvarivana. Kad se pozdravljaju kao braća ili drugovi, ljudi često nemaju nimalo bratska ili drugarska osećanja. Kako u političkom prostoru oblikovati i potvrđivati solidarnost? Možda bi ljudi pripremljeni za solidarnost uvek težili njenom unošenju u prostor politike? Kada je oslobođenje zakočeno, problemi slobode, jednakosti i bratstva ostaju nešto što ljudi mogu privremeno da potiskuju iz svesti ali ne mogu uvek da zaobilaze.

Filozofi protestvuju protiv onog što je Mil zvao "slobodomorstvo" (liberticid). Da li i njega, kao čedomorstvo, treba smatrati jednom od važnih ljudskih "'sloboda"? Uz slobodomorstvo, jako usavršeno od Milovog vremena, sloboda gubi smisao. Zašto liberticid nije poput genocida proglašen za međunarodni zločin? Zašto se ubijanje istine ne smatra zločinom? Zar je sloboda moguća bez znanja? Mil se plašio da će centralizovanje vlasti i stalno nadgledanje svih završiti proizvođenjem ' automata u ljudskom obliku". Po Milu, društvo nema pravo da kažnjava pojedince zbog neprilagođenosti. Čovečanstvo iz koga bi se izdvajao samo jedan čovek suprotnog mišljenja, ne bi imalo pravo da ga ućutka. (Mil, Dž. S., 1988: 50) Istinito uverenje postaje predrasuda ako izbegava da se suoči s drugim uverenjima. Po mnogima, nesloboda odavno nije neophodna i ljudi bi bili slobodni samo da hoće. Da li je tako? Zašto ljudi ne bi hteli slobodu? Sloboda je oblast opasnosti; da li je opasnost jedino vreme slobode? Ako svako nastoji da živi kako hoće, sloboda je onemogućena. Čak 
i ako svako živi onako kako se smatra da treba da se živi, sloboda ostaje bajka za nedorasle, teorija ubeđenih da se samo iznutra može biti slobodan. Slobode nema bez odgovornosti. Slobodan može da bude samo onaj spreman da branim slobodu. Sloboda ostaje bez neposlušnosti misaona konstrukcija. Mera dopuštenosti građanske neposlušnosti pokazuje koliko je neko društvo doista slobodno. U poretku, u kome se ne suzbija potpuno neposlušnost, još ima nade za slobodu. Poslušnost je podsticana na mnogo načina, recimo održavanjem ekonomske zavisnosti. Ljudi se često trude da se drže načela "tante za tante", ali vlast i dalje često uspešno prodaje građanima načelo "tante za kukuriku" i očekuje bezpogovorno prihvatanje. Građanska neposlušnost je važno pravo, ali se prava nekorišćenjem gube. Zašto ljudi i dalje prihvataju nepogrešivost vlasti? Kako mešavina tradicije i harizme može da bude još toliko jaka da ljudi više veruju drugima nego sebi? Oni ne bi smeli da čekaju da ih neko osposobi za slobodu. Plivanje se uči u vodi. Ljudi su do nekih sloboda uspevali da dođu, da ih osete i prave projekte svog razvoja i promene sveta, koji su uključivali i ciljanu slobodu. Kako obezbediti da velike ciljeve ne prati veliko razočaranje? Mora li epoha težnje humanosti da bude i epoha nihilizma? Ako optimist veruje da živimo u najboljem mogućem svetu, pesimist se plaši da je to možda istina.

Možda je tačno da se onima, koji se ne bave politikom, bavi politika, odnosno da oni udaljeni od političkog odlučivanja ne mogu da izbegnu dejstvo političkih odluka i da ih oni najdalji najbolnije osećaju. Odnos nadređenih i podređenih se različito uobličava. U nekim ustrojstvima su interesi i potrebe pojedinaca u drugom planu, u drugima se uzimaju u obzir. Živeti znači biti među ljudima, a u odnosima s njima nije moguće izbeći politiku. Ona je deo života, ali deo koji utiče na sve sve ostale delove. Male razlike u politici postaju velike razlike u životu. Izgleda da ni jedne ni druge razlike nije moguće ukinuti. Politika je segment društva od koga zavisi ustrojstvo celog društva i mera dozvoljene slobode u njemu. Nije jedini takav segment. Da li je najjači? Mnogi smatraju da jest, odnosno da drugi segmenti društva zavise od političkog ustrojstva. Drugi smatraju da ima i jačih segmenata. Po nekima će društvo postati bolje ako se oslobodi političkih okova koji ga sputavaju, ali je za to oslobađanje potrebna jaka politička volja. Politika zasad snažno određuje ljudsko postojanje i filozofija mora da se bavi njom.

U filozofiji ne može da se zaobiđe razmišljanje o sadašnjoj situaciji čoveka i društva. U filozofiji politike se ne mogu zanemariti "globalizovanje", a u Evropi i "evropeizovanje", jer u njoj nastoje da naprave regionalnu zajednicu koja bi sačuvala prednosti evropskih kultura i vratila kontinent, koji je nekad određivao lik sveta, u red političkih velesila. Evropski identitet može zaista da bude oblikovan ukoliko budu uništeni nacionalni identiteti, a to se ne može dogoditi preko noći. Neki Evropljani žele samo tržišno objedinjenje, drugi smatraju da građani sveta koji žive na starom kontinentu moraju da budu i politički objedinjeni. Kaže se da se u današnjem svetu igra samo jedna "politička igra", ali je pitanje ko određuje njena promenjiva pravila. Pojedini prostori se koriste i kao laboratorije u kojima se ispituju pogrešni pristupi, da bi se našli načini njihovog izbegavanja. Na nesreću je i Balkan takav prostor. "Balkanizovanje" je pojam kojim se obeležava veliko odudaranje od normi 
dostignutih u civilizovanom društvu, koje često deluje po NIMBY načelu (Not In My Backyard - ne u mom dvorištu). Zar globalizam ne bi morao da upućuje da ceo svet treba da osećam kao svoje dvorište? Izgleda da oni, koji pričaju da ceo svet treba da bude jedan, ne smatraju da rizike u njemu treba ujednačavati. Kakvo je onda doista ciljano "svetsko društvo"? Ono se obično predstavlja kao "sudbinska zajednica", odnosno zajednica koja se ne može izbeći. Kako se osećati slobodno ako je ono najvažnije predodređeno? Može li se umesto svetske moći oblikovati zajednica slobodnih građana sveta? Da li je "sudbina" ljudi da uvek ostanu daleko od slobode?

U globalizovanju se, po Harviju, prostor uništava vremenom. Države imaju korenje, a investitori krila. Cilj je da se koreni počupaju, a krila postanu što jača. Krilati neće samo da lete preko svih granica, već i da utiču na donošenje političkih odluka, a da najvažnije odluke, koje prevazilaze vidokrug ukorenjenih, donose sami. Drugim rečima, krilati teže da uvek sami uzimaju onoliko kvazi-suverenosti koliko im je potrebno. Ako ukorenjeni pokušaju da ograniče krilate, oni mogu da odlete, a za sobom ostave nezaposlene i nezadovoljne. Proizvođače je mnogo lakše naći nego kupce. Transnacionalne korporacije ne zavise od birača, već od potrošača. Da li je kupovanje postalo najvažniji vid glasanja? Krilati se oslanjaju na veću silu od ukorenjenih i ne libe se da je upotrebe. Ako krilati ostaju daleko od demokratskih pravila igre, na osnovu čega očekuju opštu saglasnost? Po Beku je demokratija poput Božić Bate. Malo ko u nju veruje, ali se mnogima sviđa. (Bek, U., Zagreb, 2004: 384) Možda svetska javnost stvara apatične koji više i ne postavljaju pitanje saglasnosti? Po Jovanu Pavlu II, demokratija ne može da bude zamena za moral, a po Benediktu XVI postoji instancija koja je iznad slučajne većine. Čovečanstvo treba zaštititi od diktature slučajnosti. (Jovan Pavle II, enciklike Fides et ratio i Evangelium vitae; Ratzinger, J., 2004: 171f) Krilati ne prihvataju nijedan vid političke odgovornosti, a na kolena može da ih obori jedino svetsko tržište. Ima, međutim, optimista koji smatraju da se globalizovanje može tako izvoditi da vodi radikalnoj demokratiji.

Ko je dobro obavešten o onom što se događa? Niko. Ko u globalizovanju donosi odluke? Niko. Ko određuje promenjiva pravila globalizovanja? Niko. Ko će da liši svet vida? Niko. Ko je kriv za patnje milijardi ljudi? Niko. Ko bi mogao da pomogne svetu? Niko. I lukavi Odisej se predstavljao kao Niko. Niko nema dom, fiksni ili mobilni telefon, e-mail adresu. Niko nije institucija protiv koje bi se moglo demonstrirati ili koja bi se mogla pozvati u pomoć. Onaj koji je protiv globalizovanja je iznenađen kada otkrije da je za drugačije globalizovanje, odnosno da i on može da se predstavlja kao niko. Derida je poručivao da je stabilizovanje potrebno zato što postoji metež, ali potpuni red i dovršena celina nisu mogući. Po Gidensu se strukture stalno stvaraju i menjaju. Objedinjavanja bez brige za humane vrednosti su opasna. Možda se neka razrešenja krize savremenog doba mogu nazreti tek posle sudara i preispitivanja odgovora na mnoga pitanja? U filozofiji se često pokazivalo da bi svet mogao da bude drugačiji i da bi njegova trenutna granica mogla da bude pređena. Problem je što su filozofi to izražavali na vrlo različite načine i što u to nikada nisu mogli da ubede dovoljno ljudi. Taština je, po Hegelu, kada se ono konačno smatra poslednjim. Da li je taština i kada se ono apsolutno proglasi za poslednje? I ljudsku 
prazninu prati taština. Iako i među filozofima ima taštih, kojima um služi za mumificiranje života, može da se kaže da prava filozofija doista uči skromnosti. Kako političare usmeriti skromnosti? Možda ih treba podsetiti da, po Montenju, i onaj koji sedi na najvišem prestolu, sedi na svojoj zadnjici?

\section{Literatura}

Acton, lord J., E ssays of F reedom and P ower, Glencoe/III, 1949.

Arent, H., Istina i laž u politici, Filip Višnjić, Beograd, 1994.

Aristotel, Politika, Globus, Liber, Zagreb, 1988.

Bek, U., Moć protiv moći u doba globalizacije. Nova svetskopolitička ekonomija, Školska knjiga, Zagreb, 2004.

Berlin, I, Concepts and Categories, Princeton University Press, Princeton, 1988.

Henis, V., Politika i praktička filozofija, Nolit, Beograd, 1983.

Laski, H., Politička gramatika, I, Beograd, 1934.

Mil, Dž. S., O slobodi, Filip Višnjić, Beograd, 1988.

Neumann, F., Demokratska i autoritarna država, Naprijed, Zagreb, 1974.

Niče, F., Volja za moć, Dereta, Beograd, 1991.

Platon, Država, BIGZ, Beograd, 1983.

Ratzinger, J., Vjera - istina - tolerancija. Kršćanstvo i svjetske religije, Kršćanska sadašnjost, Zagreb, 2004.

Rodin, D., Hermeneutička situacija suvremene njemačke filozofije, Treći program Radio Beograda, zima 1985.

Schmitt, C., P olitische Theologie, Duncker und Humblot, Berlin, 1979.

Veber, M., Privreda i društvo, II, Prosveta, Beograd, 1976. 